\title{
PENGARUH LATAR BELAKANG ETNIS, KECERDASAN ADVERSITAS \\ DAN REGULASI DIRI DALAM BELAJAR TERHADAP ORIENTASI WIRAUSAHA SISWA SMP NEGERI 31 SURABAYA
}

\author{
Setijo Wardayati, SMP Negeri 31 Surabaya \\ setiyowardayati@gmail.com
}

\begin{abstract}
ABSTRAK
Penelitian ini bertujuan untuk menganalisis pengaruh latar belakang etnis, kecerdasan adversitas dan regulasi diri dalam belajar terhadap orientasi wirausaha siswa SMP Negeri 31 Surabaya. Penelitian ini menggunakan pendekatan kuantitatif. Penelitian ini dilakukan di kelas VII dan VIII di SMP Negeri 31 Surabaya pada tahun pelajaran 2014-2015 dengan populasi 663 siswa. Sampel sebanyak 249 siswa yang dipilih secara proporsional random sampling. Data dianalisis dengan menggunakan analisis regresi berganda. Hasil penelitian menunjukkan adanya pengaruh positif dan signifikan latar belakang etnis, kecerdasan adversitas dan regulasi diri dalam belajar terhadap orientasi wirausaha siswa SMP Negeri 31 Surabaya baik secara parsial maupun secara simultan. Pengaruh latar belakang etnis, kecerdasan adversitas dan regulasi diri dalam belajar terhadap orientasi wirausaha siswa sebesar $63,8 \%$, sedangkan sisanya dipengaruhi oleh faktor lain yang tidak diteliti dalam penelitian ini.

Kata Kunci: latar belakang etnis, kecerdasan adversitas, regulasi diri dalam belajar, orientasi wirausaha.
\end{abstract}

\begin{abstract}
This study aims to analyze the influence of ethnic background, adversity quotient and self-regulated learning of the students' entrepreneurial orientation SMP Negeri 31 Surabaya. This study uses a quantitative approach. This research was conducted in class VII and VIII in SMP Negeri 31 Surabaya for academic year of 2014-2015 with population of 663 students. Sample was 249 students, selected by proportional random sampling. Data analysed using multiple regression analysis. The results showed there is positive and significant effect ethnic backgrounds, intelligence adversity and self-regulated learning of the students' entrepreneurial orientation SMP Negeri 31 Surabaya either partially or simultaneously. The influence of ethnic background, adversity quotient and selfregulated learning of the students' entrepreneurial orientation amounted to $63.8 \%$, while the rest influenced by other factors not examined in this study.

Keywords: background ethnic, adversity quotient, self-regulated learning, entrepreneurial orientation.
\end{abstract}

\section{PENDAHULUAN}

Tahun 2015 adalah tahun awal diberlakukannya ASEAN Economic Community (AEC) diantara negara-negara yang bergabung dalam Association of Southeast Asian Nations (ASEAN). Dengan adanya AEC membuat 
kawasan Asia Tenggara menjadi pasar tunggal dan berbasis produksi tunggal, dimana akan terjadi arus barang, jasa, investasi dan tenaga kerja terampil serta modal secara lebih bebas diantara negara-negara ASEAN.

Implementasi ASEAN Economic Community akan menciptakan peluang dan tantangan bagi negara dan rakyat Indonesia. Dengan adanya pasar tunggal maka akan terbuka peluang bagi wirausahawan Indonesia untuk meningkatkan pangsa pasarnya di kawasan Asia Tenggara, disisi lainnya akan terjadi arus masuk barang-barang dari luar negeri khususnya dari sesama negara-negara Asia Tenggara ke dalam negeri. Agar mampu bersaing dalam kondisi yang demikian maka wirausahawam Indonesia dituntut untuk memiliki daya saing yang tinggi, jika tidak, maka akan tersisih dan produk-produk luar negeri akan membanjiri pasar dalam negeri.

Para siswa yang duduk dibangku Sekolah Menegah Pertama saat ini adalah wirausahawan di masa yang akan datang. Sebagai wirausahawan di era globalisasi mereka dituntut untuk menjadi wirausahawan yang kompeten dan mempunyai daya saing global. Untuk itu perlu ditumbuhkembangkan kewirausahaan mereka sejak dini. Dalam menumbuh-kembangkan kewirausahaan siswa, peran guru adalah penting, guru akan membantu memahami orientasi wirausaha siswa dengan baik agar mereka kelak dapat menjadi wirausahawan yang kompeten dan sukses.

Masykur (2007) berpendapat bahwa kemampuan berwirausaha sudah saatnya mendapatkan prioritas untuk dimiliki sebagai bekal bagi para alumni selepas lulus sekolah atau kuliah. Selain mampu mengatasi pengangguran, kewirausahaan juga diyakini mampu memperkokoh ketahanan ekonomi negara melalui sektor Usaha Kecil Menegah (UKM) yang terbukti sanggup bertahan ketika krisis menerpa.

Orang yang berpotensi untuk menjadi wirausahawan adalah orang yang memiliki orientasi wirausaha (entrepreneurial orientation). Orientasi wirausaha siswa adalah kecenderungan siswa dalam bertindak mandiri, inovatif, berani mengambil resiko, proaktif dan agresif dalam bersaing. Orientasi wirausaha dikaitkan dengan proses kewirausahaan dan berkenaan dengan kegiatan-kegiatan wirausaha. Orientasi wirausaha menggambarkan proses-proses wirausaha utama dan berkenaan dengan bagaimana usaha-usaha baru dijalankan (Lumpkin dan Dess, 1996).

Menjadi seorang wirausaha merupakan pilihan yang tidak mudah, tidak semua orang berani melakukan karena dalam dunia usaha banyak ditemui hambatan, rintangan, tantangan dan resiko. Banyak pengusaha sukses membuktikan bahwa dalam dunia usaha jatuh bangun adalah hal yang biasa (Sutomo, 2007). Menjadi seorang wirausaha harus mempunyai daya juang yang tinggi. Daya juang seseorang ditentukan oleh kecerdasan adversitas yaitu kemampuan seseorang dalam menghadapi kesulitan, orang yang memiliki kecerdasan adversitas yang rendah akan mudah menyerah jika menghadapi permasalahan.

Selain harus mempunyai kecerdasan adversitas yang tinggi, seorang wirausaha untuk menjadi sukses juga harus memiliki regulasi diri yang baik. Regulasi diri adalah merupakan kemampuan sesorang mengatur dan mengelola dirinya sendiri. Jika ia mampu mengatur dan mengelola dirinya sendiri maka ia juga akan mampu mengatur dan mengelola usahanya dengan baik. 
Menurut Ullah dkk (2012) orientasi wirausaha seseorang dipengaruhi oleh faktor psikologis dan faktor non psikologis. Faktor psikologis yang mempengaruhi yaitu motivasi berprestasi, keyakinan bahwa dirinya adalah penentu nasib mereka sendiri, toleransi terhadap ambiguitas dan peran intuisi sedangkan untuk faktor non psikologis yang mempengaruhi yaitu peran pendidikan, peran beberapa ketrampilan/keragaman ketrampilan, peran hubungan formal/sosial, peran hubungan informal/pribadi.

Dari penelitian yang dilakukan oleh Vinig dan Dorresteijn (2007) diketahui bahwa orientasi wirausaha tidak diprediksi oleh karakteristik budaya suatu bangsa, tetapi Kollman dkk (2006) menyatakan bahwa pengaruh faktor lingkungan yaitu budaya, politik/hukum, mikro dan makro ekonomi pada negara-negara yang berbeda menjadi mungkin terhadap orientasi wirausaha individu.

Surabaya utara merupakan kawasan yang banyak didiami kaum urban dari daerah sekitar Surabaya termasuk dari Pulau Madura. Kondisi yang demikian menumbuhkan suatu perpaduan/akulturasi budaya antara budaya Jawa dan Madura. Menurut Yuswadi, perpaduan/akulturasi budaya antara budaya Jawa dan budaya Madura dikenal dengan budaya pandalungan. Dari penelitian-penelitian tentang kebudayaan dan kepribadian yang telah dilakukan menunjukkan besarnya pengaruh dan peranan kebudayaan sebagi faktor pembentuk watak dan kepribadian. Pewarisan kebudayaan yang dilakukan melalui proses sosialisasi sangat erat kaitannya dengan proses belajar kebudayaan dalam hubungannya dengan sistem sosial. dalam proses ini seorang individu belajar bermacam-macam pola tindakan dalam interaksi dengan semua orang di sekitarnya yang menduduki bermacam-macam status dan peranan sosialnya yang ada dalam kehidupan masyarakat sehari-hari (Kodiran, 2004).

Merujuk pada dimensi orientasi wirausaha dan berkaitan dengan faktor psikologis yang mempengaruhi orientasi wirausaha, dari beberapa penelitian terdahulu diketahui bahwa kecerdasan adversitas dan regulasi diri dalam belajar berpengaruh pada orientasi wirausaha. Kecerdasan advedrsitas (adversity quotient) adalah merupakan kemampuan seseorang dalam menghadapi kesulitan atau ketahanan seseorang terhadap situasi yang menekan (Stoltz, 2007). Sedangkan regulasi diri dalam belajar (self-regulated learning) yaitu kemampuan pebelajar untuk berpartisipasi aktif dalam proses belajarnya, baik secara metakognitif, secara motivasional dan secara perilaku (Zimmerman, 2004).

Hubungan antara kecerdasan adversitas dan regulasi diri dalam belajar dengan orientasi wirausaha telah diteliti oleh beberapa peneliti seperti yang dilakukan oleh Susanti (2013), dalam penelitiannya menunjukkan adanya hubungan yang positif dan signifikan antara daya juang dengan orientasi wirausaha dan dalam penelitian Sungur dan Tekkaya (2006) menunjukkan adanya pengaruh regulasi diri dalam belajar terhadap kemandirian siswa dimana kemandirian merupakan salah satu dimensi dari orientasi wirausaha.

Konsep tentang kecerdasan adversitas dikembangkan oleh Paul G. Stoltz dengan istilah adversity quotient. Menurut Stoltz (2007) secara garis besar adversity quotient merupakan kemampuan seseorang dalam menghadapi kesulitan atau ketahanan seseorang terhadap situasi yang menekan. Adversity 
quotient juga merupakan kemampuan individu untuk menggerakan tujuan hidup kedepan, dan juga sebagai pengukuran tentang bagaimana seseorang merespon terhadap kesulitan. Masykur (2007) menyatakan bahwa konsep apdversity quotient yang dikembangkan oleh Stoltz merupakan salah satu konsep psikologis yang berintikan tentang kecerdasan dan kemampuan untuk menghadapi kesulitan yang menghadang seseorang. Stoltz (2007) menambahkan bahwa individu yang memiliki kemampuan untuk bertahan dan terus berjuang dengan gigih ketika dihadapkan pada suatu problematika hidup, penuh motivasi, antusiasme, dorongan, ambisi, semangat, serta kegigihan yang tinggi, dipandang sebagai figur yang memiliki kecerdasan adversity yang tinggi, sedangkan individu yang mudah menyerah, pasrah begitu saja pada takdir, pesimistik dan memiliki kecenderungan untuk senantiasa bersikap negatif, dapat dikatakan sebagai individu yang memiliki tingkat kecerdasan adversity yang rendah.

Stoltz (2007) menyatakan bahwa adversity quotient (AQ) terdiri atas empat dimensi yaitu Control, Origin dan Ownership, Reach serta Endurance.Control (kendali). Control atau kendali adalah kemampuan seseorang dalam mengendalikan dan mengelola sebuah peristiwa yang menimbulkan kesulitan di masa mendatang. Origin mempertanyakan sejauh mana seseorang mempermasalahkan dirinya ketika mendapati bahwa kesalahan tersebut berasal dari dirinya, atau sejauh mana seseorang mempermasalahkan orang lain atau lingkungan yang menjadi sumber kesulitan atau kegagalan seseorang. Ownership mengungkap sejauh mana seseorang mengakui akibatakibat kesulitan dan kesediaan seseorang untuk bertanggung jawab atas kesalahan atau kegagalan tersebut. Reach (jangkauan), mempertanyakan sejauh mana kesulitan ini akan merambah kehidupan seseorang menunjukkan bagaimana suatu masalah mengganggu aktivitas lainnya, sekalipun tidak berhubungan dengan masalah yang sedang dihadapi. Endurance adalah aspek ketahanan individu. Sejauh mana kecepatan dan ketepatan seseorang dalam memecahkan masalah. Makin tinggi daya tahan seseorang, makin mampu menghadapi berbagai kesukaran yang dihadapinya.

Konsep regulasi diri dalam belajar dikenal dengan istilah self-regulated learning. Bandura mendefinisikan self-regulation learning sebagai suatu keadaan dimana individu yang belajar sebagai pengendali aktivitas belajarnya sendiri, memonitor motivasi dan tujuan akademik, mengelola sumber daya manusia dan benda serta menjadi perilaku dalam proses pengambilan keputusan dan pelaksana dalam proses belajar (Filho, 2004). Lebih lanjut Zimmerman (2004) mendefinisikan Self-regulated learning sebagai kemampuan pebelajar untuk berpartisipasi aktif dalam proses belajarnya, baik secara metakognitif, secara motivasional dan secara behavioral/perilaku. Secara metakognitif, individu yang meregulasi diri merencanakan, mengorganisasi, menginstruksi diri, memonitor dan mengevaluasi dirinya dalam proses belajar. Secara motivasional, individu yang belajar merasa bahwa dirinya kompeten, memiliki keyakinan diri (self-efficacy) dan memiliki kemandirian. Sedangkan secara behavioral, individu yang belajar menyeleksi, menyusun dan menata lingkungan agar lebih optimal dalam belajar.

Menurut Pintrich (Wolters dkk, 2003), strategi pengaturan diri dalam belajar secara umum meliputi tiga macam strategi, yaitu strategi regulasi 
kognitif, strategi regulasi motivasional, dan strategi regulasi behavioral akademik. Strategi regulasi kognitif, merupakan strategi yang berhubungan dengan pemrosesan informasi yang berkaitan dengan berbagai jenis kegiatan kognitif dan metakognitif yang digunakan individu untuk menyesuaikan dan merubah kognisinya, mulai dari strategi memori yang paling sederhana, hingga strategi yang lebih rumit. Strategi kognitif meliputi; rehersal, elaborasi, dan organisasi dan metakognisi. Strategi regulasi motivasional, merupakan strategi yang digunakan individu untuk mengatasi stres dan emosi, yang dapat membangkitkan usaha mengatasi kegagalan dan untuk meraih kesuksesan dalam belajar (Cobb, 2003). Secara umum strategi regulasi motivasional mencakup; pemikiran-pemikiran, tindakan atau perilaku yang dilakukan individu untuk mempengaruhi pilihan, usaha dan ketekunannya terhadap berbagai tugas akademis. Strategi regulasi motivasional menurut Wolters dan Rosenthal (dalam Wolters dkk, 2003), meliputi tujuh strategi yaitu (1) konsekuensi diri, (2) kelola lingkungan (environmental structuring), (3) orientasi penguasaan, (4) meningkatkan motivasi ekstrinsik (extrinsic self-talk), (5) orientasi kemampuan (relative ability self-talk), (6) motivasi intrinsik, dan (7) relevansi pribadi (relevance enhancement). Strategi regulasi behavioral, merupakan aspek regulasi diri yang melibatkan usaha individu untuk mengontrol tindakan dan perilakunya sendiri (Pintrich, 2004). Strategi regulasi behavioral yang dapat dilakukan oleh individu dalam belajar meliputi : mengatur usaha (effort regulation), mengatur waktu dan lingkungan belajar (regulating time and study environmet) serta mencari bantuan (help-seeking).

Konsep orientasi wirausaha (entrepreneurial orientation) isampaikan oleh Lumpkin dan Dess. Orientasi wirausaha sebaiknya dimiliki oleh wirusahawan. Wirausahawan yang memiliki orientasi wirausaha yang tinggi akan mampu bersaing dalam ketatnya pasar global. Orientasi wirausaha memiliki hubungan dengan keberhasilan wirausahawan, seperti dalam penelitian yang dilakukan oleh oleh Frese dkk. (2002) bahwa ada hubungan positif yang signifkan antara orientasi wirausaha dengan keberhasilan pada pemilik bisnis kecil di Namibia.

Orientasi wirausaha menggambarkan proses-proses wirausaha utama dan berkenaan dengan bagaimana usaha-usaha baru dijalankan. Orientasi wirausaha memiliki beberapa dimensi yaitu otonomi, inovatif, berani mengambil resiko, bertindak proaktif dan agresif dalam bersaing (Lumpkin dan Dess, 1996). Seseorang yang memiliki orientasi wirausaha yang tinggi, akan memenuhi dimensi-dimensi orientasi wirausaha tersebut. Lumpkin dan Dess (1996) menjelaskan bahwa : Otonomi adalah tindakan individu atau tim yang membawa ide-ide atau visi baru dan berupaya untuk mencapainya. Inovatif yaitu kecenderungan seseorang terlibat dan mendukung dalam ide-ide baru, pembaharuan, eksperimen, dan proses-proses kreatif yang mungkin menghasilkan produk, atau proses teknologi baru. Berani megambil resiko memiliki arti keberanian untuk mengambil resiko atas segala keputusan yang diambilnya. Proaktif yaitu keberanian untuk melakukan tindakan guna menghadapi permasalahan didepan, kebutuhan atau perubahan yang mengkin terjadi. Agresif dalam bersaing adalah sebuah kecenderungan seseorang secara langsung dan intens menantang pesaingnya untuk mencapai suatu posisi atau memperbaiki posisi. 


\section{METODE PENELITIAN}

Subjek dalam penelitian ini adalah 249 siswa SMP Negeri 31 Surabaya kelas VII dan VIII tahun pelajaran 2014-2015 yang dipilih secara proportional random sampling. Variabel-variabel yang digunakan dalam penelitian ini terdiri dari variabel terikat yaitu orientasi wirausaha siswa serta variabel bebas yaitu latar belakang etnis, kecerdasan adversitas dan regulasi diri dalam belajar siswa.

Setiap subjek penelitian mendapatkan satu set instrumen penelitian yang terdiri dari kuesioner latar belakang etnis, kuesioner kecerdasan adversitas, kuesioner regulasi diri dalam belajar dan kuesioner orientasi wirausaha. Untuk kuesioner latar belakang etnis menggunakan jawaban terbuka sedangkan untuk kuesioner kecerdasan adversitas, regulasi diri dalam belajar dan orientasi wirausaha menggunakan empat alternatif jawaban yaitu sangat sesuai (SS), sesuai (S), tidak sesuai (TS) dan sangat tidak sesuai (STS) dengan skor antara 1- 4. Untuk kuesioner latar belakang etnis terdiri dari 5 item petanyaan dan untuk kuesioner kecerdasan adversitas, regulasi diri dalam belajar serta orientasi wirausaha masing-masing terdiri dari 20 item pernyataan.

Teknik analisis data yang digunakan adalah teknik analisis regresi linier berganda, uji asumsi klasik, uji signifikansi dan uji determinasi. Analisis data dilakukan dengan bantuan software Statistical Product for Service Solution (SPSS).

\section{HASIL PENELITIAN DAN PEMBAHASAN}

Berikut adalah deskripsi variabel penelitian, data yang dideskripsikan diperoleh dari penyebaran kuesioner kepada responden :

1. Latar belakang etnis responden

Berdasarkan latar belakang etnis menunjukkan sebanyak 132 responden atau $53,01 \%$ responden mempunyai latar belakang etnis Jawa sedangkan sisanya sebanyak 117 responden atau 46,98\% responden mempunyai latar belakang etnis Madura.

2. Kecerdasan adversitas responden

Berdasar kategori yang ditetapkan yaitu jika responden memiliki skor antara 21-40 termasuk kategori rendah, skor antara 41-60 termasuk kategori sedang dan skor antara 61-80 termasuk kategori tinggi maka dari hasil kuesioner yang disebar didapat data : sebanyak 211 atau 84,73\% responden mempunyai kecerdasan adversitas termasuk kategori tinggi dan 38 atau $15,26 \%$ responden mempunyai kecerdasan adversitas termasuk kategori sedang. 
Tabel 1. Distribusi Frekuensi dan Nilai Rata-rata Indikator Variabel Kecerdasan Adversitas

\begin{tabular}{|c|c|c|c|c|c|c|c|c|c|}
\hline \multirow{2}{*}{ No. } & \multirow{2}{*}{ Indikator } & \multirow{2}{*}{$\begin{array}{l}\text { No. } \\
\text { Item }\end{array}$} & \multicolumn{4}{|c|}{ Skor } & \multirow{2}{*}{\multicolumn{2}{|c|}{$\begin{array}{c}\text { Nilai } \\
\text { Rata-rata }\end{array}$}} & \multirow{2}{*}{ Ket. } \\
\hline & & & \multirow[t]{2}{*}{1} & \multirow[t]{2}{*}{2} & \multirow[t]{2}{*}{3} & \multirow[t]{2}{*}{4} & & & \\
\hline \multicolumn{3}{|c|}{ Kendali } & & & & & & & \\
\hline \multirow{10}{*}{1.} & \multirow{10}{*}{$\begin{array}{l}\text { Mengendalikan dan } \\
\text { mengelolah peristiwa }\end{array}$} & \multirow{2}{*}{1} & - & 2 & 116 & 131 & \multirow{2}{*}{3,52} & \multirow{10}{*}{3,47} & \multirow{10}{*}{ tinggi } \\
\hline & & & - & 0,8 & 46,6 & 52,6 & & & \\
\hline & & \multirow{2}{*}{2} & 2 & 15 & 171 & 61 & \multirow{2}{*}{3,17} & & \\
\hline & & & 0,8 & 6,2 & 68,7 & 24,5 & & & \\
\hline & & \multirow{2}{*}{3} & - & 14 & 113 & 122 & & & \\
\hline & & & - & 5,6 & 45,4 & 49 & 3,43 & & \\
\hline & & & - & - & 103 & 146 & & & \\
\hline & & 4 & - & - & 41,4 & 58,6 & 3,59 & & \\
\hline & & & - & 1 & 82 & 166 & & & \\
\hline & & 5 & - & 0,4 & 32,9 & 66,7 & 3,66 & & \\
\hline Asal & usul & & & & & & & & \\
\hline & Mempermasalahkan & & - & 6 & 90 & 153 & & & \\
\hline 2. & $\begin{array}{l}\text { dirinya, orang lain } \\
\text { dan lingkungan }\end{array}$ & 6 & - & 2,4 & 36,1 & 61,4 & 3,59 & 3,59 & Tinggi \\
\hline Peng & kuan & & & & & & & & \\
\hline & & 7 & - & 8 & 113 & 128 & 348 & & \\
\hline & & 1 & - & 3,2 & 45,4 & 51,4 & 3,48 & & \\
\hline & Mengakui akibat- & 8 & - & 3 & 101 & 145 & 357 & & \\
\hline 3 & akibat kesulitan dan & 8 & - & 1,2 & 40,6 & 58,2 & $3,5 /$ & & \\
\hline 3. & kesediaan untuk & 0 & - & 5 & 104 & 140 & & 3,50 & Tingg1 \\
\hline & bertanggung jawab & 9 & - & 2,0 & 41,8 & 56,2 & 3,54 & & \\
\hline & & & 1 & 4 & 132 & 112 & & & \\
\hline & & 10 & 0,4 & 1,6 & 53,0 & 49,9 & 4,43 & & \\
\hline Jang & auan & & & & & & & & \\
\hline & & & 1 & 49 & 160 & 39 & & & \\
\hline & & 11 & 0,4 & 19,7 & 64,3 & 15,7 & 2,95 & & \\
\hline & & & 5 & 72 & 138 & 34 & & & \\
\hline & & 12 & 2,0 & 28,9 & 55,4 & 13,7 & 2,81 & & \\
\hline 4 & Jangkauan dampak & & - & 28 & 153 & 68 & & 308 & Tingri \\
\hline 4. & kesulitan & 13 & - & 11,2 & 61,4 & 27,3 & 3,16 & 3,08 & lingg1 \\
\hline & & 14 & 1 & 46 & 138 & 64 & 306 & & \\
\hline & & 14 & 0,4 & 18,5 & 55,4 & 25,7 & 3,00 & & \\
\hline & & 15 & 1 & 13 & 117 & 118 & 341 & & \\
\hline & & 15 & 0,4 & 5,2 & 46,9 & 47,4 & 3,41 & & \\
\hline Day: & tahan & & & & & & & & \\
\hline & & 16 & 1 & 30 & 134 & 84 & 321 & & \\
\hline & & 10 & 0,4 & 12,0 & 53,8 & 33,7 & 3,21 & & \\
\hline & & & - & 30 & 128 & 91 & 324 & & \\
\hline & & 17 & - & 12,0 & 51,4 & 36,5 & 3,24 & & \\
\hline 5 & Kecepatan dan & 18 & - & 60 & 119 & 124 & 347 & 34 & Tincri \\
\hline J. & ketepatan & 18 & - & 2,4 & 47,8 & 49,8 & 3,47 & 3,42 & lingg1 \\
\hline & & 10 & - & 3 & 53 & 193 & 376 & & \\
\hline & & 19 & - & 1,2 & 21,3 & 77,3 & 3,76 & & \\
\hline & & & - & 8 & 126 & 115 & & & \\
\hline & & 20 & - & 3,2 & 50,6 & 46,2 & 3,43 & & \\
\hline & Nilai rata-rata & & & & & & & 3,41 & Tinggi \\
\hline
\end{tabular}


Tabel 2. Distribusi Frekuensi dan Nilai Rata-rata Indikator Variabel Regulasi Diri dalam Belajar

\begin{tabular}{|c|c|c|c|c|c|c|c|c|c|}
\hline \multirow{2}{*}{ No. } & \multirow{2}{*}{ Indikator } & \multirow{2}{*}{$\begin{array}{l}\text { No. } \\
\text { Item }\end{array}$} & \multicolumn{4}{|c|}{ Skor } & \multirow{2}{*}{\multicolumn{2}{|c|}{$\begin{array}{l}\text { Nilai } \\
\text { Rata-rata }\end{array}$}} & \multirow{3}{*}{ Ket. } \\
\hline & & & \multirow[t]{2}{*}{1} & \multirow[t]{2}{*}{2} & \multirow[t]{2}{*}{3} & \multirow[t]{2}{*}{4} & & & \\
\hline Strat & gi regulasi kognitif & & & & & & & & \\
\hline \multirow{12}{*}{1.} & \multirow{12}{*}{$\begin{array}{l}\text { Regulasi diri dalam } \\
\text { belajar }\end{array}$} & \multirow{2}{*}{1} & - & 36 & 137 & 76 & \multirow{2}{*}{3,16} & \multirow{12}{*}{3,11} & \multirow{12}{*}{ Tinggi } \\
\hline & & & - & 14,5 & 55,0 & 30,6 & & & \\
\hline & & \multirow{2}{*}{2} & - & 53 & 168 & 28 & \multirow{2}{*}{2,90} & & \\
\hline & & & - & 21,3 & 67,5 & 11,2 & & & \\
\hline & & \multirow{2}{*}{3} & 1 & 56 & 139 & 53 & \multirow{2}{*}{2,98} & & \\
\hline & & & 0,4 & 22,5 & 55,8 & 21,3 & & & \\
\hline & & \multirow{2}{*}{4} & 1 & 40 & 127 & 81 & & & \\
\hline & & & 0,4 & 16,0 & 51,0 & 32,5 & 3,16 & & \\
\hline & & & - & 30 & 136 & 83 & & & \\
\hline & & 5 & - & 12,0 & 54,6 & 32,5 & 3,21 & & \\
\hline & & & 1 & 28 & 158 & 62 & & & \\
\hline & & 6 & 0,4 & 11,2 & 63,4 & 24,8 & 3,13 & & \\
\hline Strat & gi regulasi motivasio & & & & & & & & \\
\hline & & 7 & - & 38 & 138 & 73 & & & \\
\hline & & 1 & - & 15,3 & 55,4 & 29,3 & 3,14 & & \\
\hline & Konsekuen, kelola & & - & 18 & 127 & 104 & & & \\
\hline & lingkungan, & $\gamma$ & - & 7,2 & 51,0 & 41,7 & 3,34 & & \\
\hline & orientasi & 0 & - & 3 & 89 & 157 & 362 & & \\
\hline 2. & penguasaan dan & 9 & - & 1,2 & 35,7 & 63,0 & 3,02 & & \\
\hline & kemampuan, & & - & 1 & 49 & 199 & & 3,52 & Tingg1 \\
\hline & motivasi intrinsik & 10 & - & 0,4 & 19,6 & 79,9 & 3,79 & & \\
\hline & dan ekstrinsik, & 11 & - & 5 & 66 & 178 & 369 & & \\
\hline & relevansi diri & 11 & - & 2,0 & 26,5 & 71,5 & 3,09 & & \\
\hline & & & - & 1 & 117 & 131 & & & \\
\hline & & 12 & - & 0,4 & 46,9 & 52,6 & 3,52 & & \\
\hline Stra & gi behavior akademi & & & & & & & & \\
\hline & & & - & 16 & 146 & 87 & & & \\
\hline & & 13 & - & 6,4 & 58,6 & 34,9 & 3,28 & & \\
\hline & & & - & 21 & 138 & 90 & & & \\
\hline & & 14 & - & 8,4 & 55,4 & 36,1 & 3,28 & & \\
\hline & & & - & 49 & 133 & 67 & & & \\
\hline & & 15 & - & 19,6 & 53,4 & 26,9 & 3,07 & & \\
\hline & Mengatur usaha, & & 1 & 27 & 126 & 95 & & & \\
\hline 3 & $\begin{array}{l}\text { waktu dan } \\
\text { linokungan helaiar }\end{array}$ & 16 & 0,4 & 10,8 & 50,6 & 38,1 & 3,26 & 327 & Tinooi \\
\hline 3. & $\begin{array}{l}\text { lingkungan belajar } \\
\text { serta mencari }\end{array}$ & 17 & - & 6 & 130 & 113 & 343 & 3,21 & IInggi \\
\hline & bantuan & 17 & - & 2,4 & 52,2 & 45,4 & 3,43 & & \\
\hline & & 18 & - & 9 & 84 & 156 & 350 & & \\
\hline & & 18 & - & 3,6 & 33,7 & 62,7 & 3,39 & & \\
\hline & & 10 & - & 15 & 107 & 127 & 345 & & \\
\hline & & 19 & - & 6,0 & 42,9 & 51,0 & 3,45 & & \\
\hline & & 20 & 11 & 88 & 99 & 51 & & & \\
\hline & & 20 & 4,4 & 35,3 & 39,6 & 20,5 & 2,16 & & \\
\hline & Nilai rata-rata & & & & & & & 3,30 & Tinggi \\
\hline
\end{tabular}

Menurut kategori yang ditetapkan yaitu jika nilai rata-rata indikator antara 1,01-2,00 termasuk kategori rendah, nilai rata-rata antara 2,01-3,00 termasuk kategori sedang dan nilai rata-rata antara 3,01-4,00 termasuk kategori tinggi maka dari tabel diatas tampak bahwa nilai rata-rata untuk masing-masing indikator termasuk dalam kategori tinggi begitu juga untuk nilai rata-rata 
seluruh indikator, hal ini menunjukkan bahwa siswa SMP Negeri 31 Surabaya memiliki kecerdasan adversitas dalam kategori tinggi dan berarti Siswa SMP Negeri 31 Surabaya telah memiliki kemampuan dalam mengendalikan dan mengelolah masalah / peristiwa, dapat mengetahui asal usul permasalahan yang dihadapi, mengakui akibat-akibat adanya kesulitan dan bersedia untuk bertanggung jawab, mampu melihat dampak kesulitan yang sedang dihadapi dan memiliki kemampuan dalam mengatasi masalah yang sedang dihadapi dengan cepat dan tepat.

3. Regulasi diri dalam belajar responden

Berdasar kategori yang ditetapkan yaitu jika responden memiliki skor antara 21-40 termasuk kategori rendah, skor antara 41-60 termasuk kategori sedang dan skor antara 61-80 termasuk kategori tinggi maka dari hasil kuesioner yang disebar didapat data : sebanyak 196 atau 78,71\% responden mempunyai regulasi diri dalam belajar termasuk kategori tinggi dan 53 atau $21,28 \%$ responden mempunyai regulasi dalam belajar termasuk kategori sedang.

Berdasar kategori yang ditetapkan yaitu jika nilai rata-rata indikator antara 1,01-2,00 termasuk kategori rendah, nilai rata-rata antara 2,01-3,00 termasuk kategori sedang dan nilai rata-rata antara 3,01-4,00 termasuk kategori tinggi maka dari tabel diatas tampak bahwa nilai rata-rata untuk masing-masing indikator termasuk dalam kategori tinggi dan untuk nilai rata-rata seluruh indikator juga termasuk dalam kategori tinggi, hal ini menunjukkkan bahwa siswa SMP Negeri 31 Surabaya memiliki kemampuan regulasi diri dalam belajar kategori tinggi dan hal ini berarti bahwa siswa SMP Negeri 31 Surabaya telah memiliki kemampuan dalam meregulasi diri dalam belajar, konsekuen, kelolah lingkungan, orientasi penguasaan dan kemampuan, motivasi intrinsik dan ekstrinsik, relevansi diri, mengatur usaha, waktu dan lingkungan belajar serta mencari bantuan.

4. Orientasi wirausaha responden

Berdasar kategori yang ditetapkan yaitu jika responden memiliki skor antara 21-40 termasuk kategori rendah, skor antara 41-60 termasuk kategori sedang dan skor antara 61-80 termasuk kategori tinggi maka dari hasil kuesioner yang disebar didapat data : sebanyak 189 atau 75,90\% responden mempunyai orientasi wirausaha termasuk kategori tinggi dan sebanyak 60 atau $24,09 \%$ responden mempunyai orientasi wirausaha termasuk kategori sedang.

Berdasar kategori yang ditetapkan yaitu jika nilai rata-rata indikator antara 1,01-2,00 termasuk kategori rendah, nilai rata-rata antara 2,01-3,00 termasuk kategori sedang dan nilai rata-rata antara 3,01-4,00 termasuk kategori tinggi maka dari tabel diatas tampak bahwa nilai rata-rata untuk masing-masing indikator termasuk dalam kategori tinggi dan untuk nilai rata-rata seluruh indikator juga termasuk dalam kategori tinggi, hal ini menunjukkan bahwa siswa SMP Negeri 31 Surabaya memiliki orientasi wirausaha dalam kategori tinggi, dan hal ini berarti bahwa siswa SMP Negeri 31 Surabaya telah memiliki kemandirian, inovatif, kreatif, berorientasi pada peluang, berusaha berprestasi, aktif, dinamis, dan tanggap menghadapi persaingan. 
Tabel 3. Distribusi frekuensi dan Nilai Rata-rata Indikator Variabel Orientasi Wirausaha

\begin{tabular}{|c|c|c|c|c|c|c|c|c|c|}
\hline \multirow{2}{*}{ No. } & \multirow{2}{*}{ Indikator } & \multirow{2}{*}{$\begin{array}{l}\text { No. } \\
\text { Item }\end{array}$} & \multicolumn{4}{|c|}{ Skor } & \multirow{2}{*}{\multicolumn{2}{|c|}{$\begin{array}{l}\text { Nilai } \\
\text { Rata-rata }\end{array}$}} & \multirow{3}{*}{ Ket. } \\
\hline & & & \multicolumn{4}{|c|}{ Skor } & & & \\
\hline \multicolumn{9}{|c|}{ Otonomi } & \\
\hline \multirow{8}{*}{1.} & \multirow{8}{*}{ Bertindak mandiri } & \multirow{2}{*}{1} & - & 94 & 142 & 13 & \multirow{2}{*}{2,67} & \multirow{8}{*}{3,05} & \multirow{8}{*}{ Tinggi } \\
\hline & & & - & 37,8 & 57,0 & 5,2 & & & \\
\hline & & \multirow{2}{*}{2} & - & 21 & 119 & 109 & \multirow{2}{*}{3,35} & & \\
\hline & & & - & 8,4 & 47,8 & 43,8 & & & \\
\hline & & \multirow{2}{*}{3} & - & 26 & 126 & 97 & \multirow{2}{*}{3,28} & & \\
\hline & & & - & 10,4 & 50,6 & 38,9 & & & \\
\hline & & \multirow{2}{*}{4} & 1 & 68 & 133 & 47 & \multirow{2}{*}{2,91} & & \\
\hline & & & 0,4 & 27,3 & 53,4 & 18,9 & & & \\
\hline Inov & & & & & & & & & \\
\hline & & 5 & 1 & 19 & 136 & 93 & 220 & & \\
\hline & & 5 & 0,4 & 7,6 & 54,5 & 37,7 & 3,29 & & \\
\hline & & & - & 59 & 126 & 64 & & & \\
\hline 2 & Berinovasi dan & 6 & - & 23,7 & 50,6 & 25,7 & 3,02 & 203 & Tingri \\
\hline 2. & kreatif & & 4 & 77 & 98 & 70 & & 3,03 & 1ingg1 \\
\hline & & 7 & 1,6 & 30,9 & 39,4 & 28,1 & 2,94 & & \\
\hline & & & - & 71 & 137 & 41 & & & \\
\hline & & 8 & - & 28,5 & 55,0 & 16,4 & 2,88 & & \\
\hline Bera & i mengambil resiko & & & & & & & & \\
\hline & & 0 & - & 14 & 129 & 106 & 337 & & \\
\hline & & 9 & - & 5,6 & 51,8 & 42,6 & 3,31 & & \\
\hline & & 10 & - & 16 & 145 & 88 & & & \\
\hline 3 & Berorientasi pada & 10 & - & 6,42 & 58,2 & 35,3 & 3,29 & 338 & \\
\hline 3. & peluang & & - & 5 & 123 & 121 & & 3,38 & lingg1 \\
\hline & & 11 & - & 2,0 & 49,4 & 48,6 & 3,47 & & \\
\hline & & 12 & - & 16 & 118 & 115 & & & \\
\hline & & 12 & - & 6,42 & 47,4 & 46,2 & 3,40 & & \\
\hline Proa & & & & & & & & & \\
\hline & & & - & 9 & 131 & 109 & & & \\
\hline & & 13 & - & 3,6 & 52,6 & 43,4 & 3,40 & & \\
\hline & & 14 & - & 2 & 82 & 165 & & & \\
\hline 4 & $\begin{array}{l}\text { Berusaha } \\
\text { bernrestasi aktif }\end{array}$ & & - & 0,8 & 32,9 & 66,3 & 3,65 & 320 & Tinoi \\
\hline 4. & berprestas1, aKtiI & & - & 35 & 147 & 67 & & 3,29 & lingg1 \\
\hline & & 15 & - & 14,0 & 59,0 & 26,9 & 3,13 & & \\
\hline & & 16 & 3 & 54 & 139 & 53 & 207 & & \\
\hline & & 10 & 1,2 & 21,7 & 55,8 & 21,3 & 2,91 & & \\
\hline Agr & if dalam bersaing & & & & & & & & \\
\hline & & 17 & 2 & 45 & 129 & 73 & 300 & & \\
\hline & & 17 & 0,8 & 18,0 & 51,8 & 29,3 & 3,09 & & \\
\hline & & 18 & - & 25 & 114 & 110 & 334 & & \\
\hline 5. & menghadapi & 18 & - & 10,0 & 45,8 & 44,2 & 5,34 & 342 & Tinogi \\
\hline & persaingan & 19 & - & 8 & 90 & 151 & 3.57 &, $4+2$ & IIIIgg \\
\hline & & 19 & - & 3,2 & 36,1 & 60,6 & & & \\
\hline & & 20 & - & 7 & 71 & 171 & & & \\
\hline & & 20 & - & 2,8 & 28,5 & 68,7 & 3,66 & & \\
\hline & Nilai rata-rata & & & & & & & 3,23 & Tinggi \\
\hline
\end{tabular}




\section{Uji Persyaratan Analisis}

Sebelum data diuji dengan analisis regresi linier berganda dilakukan uji asumsi klasik terlebih dahulu sebagai syarat diterimanya analisis regresi. Berdasar grafik histogram dan grafik normal probability plot of regression standardized residual dapat disimpulkan bahwa grafik histogram memberikan pola distribusi yang normal dan pada grafik normal probability plot of regression standardized residual terlihat titik-titik menyebar disekitar garis diagonal dan mengikuti garis diagonal. Kedua grafik menunjukkan bahwa model regresi tidak menyalahi asumsi normalitas. Jadi dapat disimpulkan bahwa model regresi pada penelitian ini memenuhi syarat untuk menjadi model regresi yang baik karena merupakan model regresi yang memiliki distribusi data normal.

Histogram

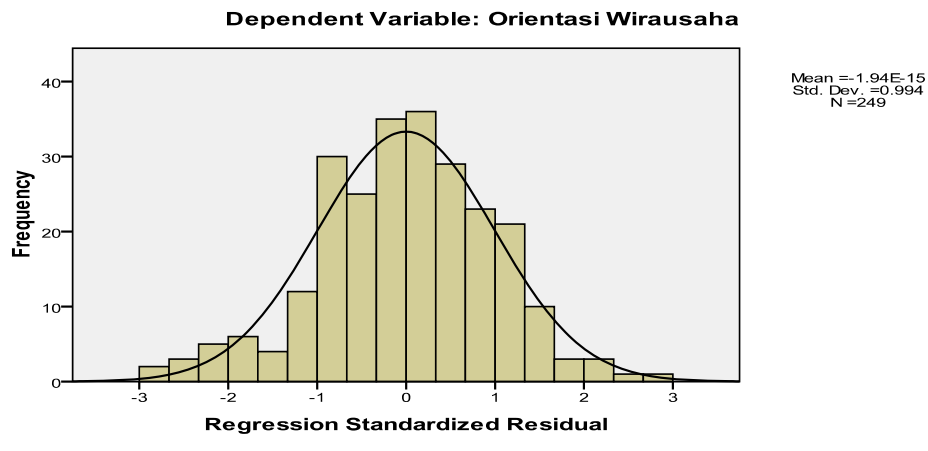

Grafik 1

Histogram Regression Standardized

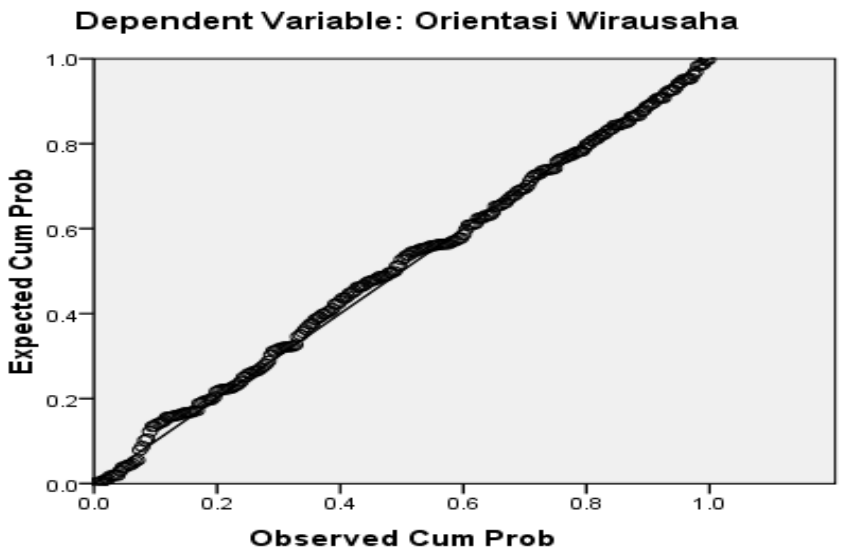

Grafik 2

Normal Probability Plot Regression Standardized Residual

Berdasarkan uji multikolinearitas menunjukkan bahwa variance inflation factor (VIF) dari ketiga variabel bebas bernilai kurang dari 5 (VIF < 5) hal ini berarti bahwa variabel latar belakang etnis, kecerdasan adversitas dan regulasi diri dalam belajar tidak memiliki hubungan multikolinieritas. Dari hasil tersebut maka dapat disimpulkan bahwa model pada penelitian ini memenuhi syarat untuk menjadi model regresi yang baik karena tidak terjadi korelasi antar variabel bebas (non-multikolinearitas). 
Berdasarkan hasil uji heteroskedastisitas menghasilkan $\mathrm{p}>0,05$, hal ini menunjukkan tidak terjadi heteroskedastisitas sehingga data variabel latar belakang etnis, kecerdasan adversitas dan regulasi diri dalam belajar dapat digunakan dalam penelitian ini dan berdasarkan uji linieritas nampak bahwa deviation from linearity dari ketiga variabel bebas terhadap variabel terikat bernilai lebih dari 0,05 . Hal ini berarti bahwa antara variabel bebas, yaitu latar belakang etnis, kecerdasan adversitas dan regulasi diri dalam belajar mempunyai hubungan linier dengan variabel terikat, yaitu orientasi wirausaha siswa SMP Negeri 31 Surabaya.

Tabel 4. Hasil Uji Linieritas

\begin{tabular}{|l|c|c|}
\hline Variabel & $\begin{array}{l}\text { Deviation from } \\
\text { Linearity }(>0,05)\end{array}$ & Keterangan \\
\hline $\begin{array}{l}\text { Orientasi Wirausaha (Y) } \\
\text { *Latar Belakang Etnis }\left(\mathrm{X}_{1}\right)\end{array}$ & 2,336 & Linier \\
\hline $\begin{array}{l}\text { Orientasi Wirausaha }(\mathrm{Y}) \\
\text { *Kecerdasan Adversitas }\left(\mathrm{X}_{2}\right)\end{array}$ & 0,949 & Linier \\
\hline $\begin{array}{l}\text { Orientasi Wirausaha (Y) } \\
\text { *Regulasi Diri dalam Belajar }\left(\mathrm{X}_{3}\right)\end{array}$ & 1,419 & Linier \\
\hline
\end{tabular}

6. Pengujian Hipotesis

Berdasarkan hasil uji t menunjukkan bahwa nilai $t$ hitung untuk constant yaitu 2,711, pada $t$ tabel dengan db 249 dan taraf signifikan 0,05 diperoleh 1,96954. Karena $t$ hitung $>t$ tabel maka Ho ditolak. Berdasarkan analisis diatas maka dapat dibuat model regresi dugaanya yaitu $\mathrm{Y}=15,020$. Nilai $\mathrm{t}$ hitung untuk latar belakang etnis yaitu 8,238, pada $\mathrm{t}$ tabel dengan $\mathrm{db} 249$ dan taraf signifikan 0,05 diperoleh 1,96954, karena $\mathrm{t}$ hitung $>\mathrm{t}$ tabel maka Ho ditolak. Hipotesis ke 1 diterima dan teruji kebenarannya sehingga dapat disimpulkan bahwa latar belakang etnis secara parsial berpengaruh signifikan terhadap orientasi wirausaha siswa.

Nilai $t$ hitung untuk kecerdasan adversitas yaitu 7,889, pada $t$ tabel dengan $d b$ 249 dan taraf signifikan 0,05 diperoleh 1,96954, karena $t$ hitung $>t$ tabel maka Ho ditolak. Hipotesis ke 2 diterima dan teruji kebenarannya sehingga dapat disimpulkan bahwa kecerdasan adversitas secara parsial berpengaruh signifikan terhadap orientasi wirausaha siswa. Nilai $t$ hitung untuk regulasi diri dalam belajar yaitu 6,587, pada $\mathrm{t}$ tabel dengan db 249 dan taraf signifikan 0,05 diperoleh 1,96954, karena $t$ hitung $>t$ tabel maka Ho ditolak. Hipotesis ke 3 diterima dan teruji kebenarannya sehingga dapat disimpulkan bahwa regulasi diri dalam belajar siswa secara parsial berpengaruh signifikan terhadap orientasi wirausaha siswa.

Dari hasil uji $\mathrm{F}$ dapat dilihat bahwa nilai $\mathrm{F}$ hitung yaitu 146,706, sedangkan nilai $\mathrm{F}$ tabel yang diperoleh dengan menggunakan tabel $\mathrm{F}$ dengan derajat bebas (df) Residual (sisa) yaitu 245 sebagai df penyebut dan df Regression (perlakuan) yaitu 3 sebagai df pembilang dengan taraf signifikan 0,05 diperoleh nilai $F$ tabel yaitu 2,6414 . Karena $F$ hitung $(146,706)>F$ tabel $(2,6414)$ maka model signifikan. Berdasarkan nilai signifikan maka Ho ditolak. Hipotesis ke 4 diterima dan teruji kebenarannya sehingga dapat disimpulkan bahwa latar belakang etnis, kecerdasan adversitas dan regulasi diri dalam belajar siswa secara simultan berpengaruh signifikan terhadap 
orientasi wirausaha siswa. Dilihat dari hasil diatas, maka model regresi dapat dipakai untuk memprediksi orientasi wirausaha.

Berdasarkan hasil uji koefisien determinasi diketahui bahwa nilai Adjusted $R$ Square adalah 0,638, hal ini menunjukkan bahwa latar belakang etnis, kecerdasan adversitas dan regulasi diri dalam belajar berpengaruh 63,8 \% terhadap orientasi wirausaha dan sisanya $36,2 \%$ dipengaruhi oleh variabel lain yang tidak diteliti

Berdasarkan hasil analisis regresi yang dilakukan, didapat hasil seperti pada tabel dibawah ini :

Tabel 5. Analisis Regresi

\begin{tabular}{|c|c|c|c|c|c|}
\hline \multirow[b]{2}{*}{ Model } & \multicolumn{2}{|c|}{$\begin{array}{l}\text { Unstandardized } \\
\text { Coefficients }\end{array}$} & \multirow{2}{*}{$\begin{array}{c}\begin{array}{c}\text { Standardized } \\
\text { Coefficients }\end{array} \\
\text { Beta }\end{array}$} & \multirow[b]{2}{*}{$\mathrm{t}$} & \multirow[b]{2}{*}{ Sig. } \\
\hline & B & Std. Error & & & \\
\hline (Constant) & 15.020 & 2.933 & & 2.711 & .038 \\
\hline Latar Belakang Etnis & .617 & .093 & .509 & 8.238 & .000 \\
\hline Kecerdasan Adversitas & .506 & .064 & .466 & 7.889 & .000 \\
\hline $\begin{array}{l}\text { Regulasi Diri dalam } \\
\text { Belajar }\end{array}$ & .387 & .059 & .389 & 6.587 & .000 \\
\hline
\end{tabular}

a. Dependent Variable: Orientasi Wirausaha

dari tabel diatas maka dapat ditulis bentuk persamaan regresi linier bergandanya sebagai berikut:

$$
\mathrm{Y}=15,020+0,617 \mathrm{X}_{1}+0,506 \mathrm{X}_{2}+0,387 \mathrm{X}_{3}+\mathrm{ei}
$$

Hasil persamaan analisis regresi linier berganda di atas dapat diinterpretasikan sebagai berikut:

a. Nilai konstanta $(\alpha)$ sebesar 15,020 artinya jika nilai variabel latar belakang etnis $\left(\mathrm{X}_{1}\right)$,

variabel kecerdasan adversitas $\left(\mathrm{X}_{2}\right.$,) dan regulasi diri dalam belajar $\left(\mathrm{X}_{3}\right)$ adalah nol (0),

maka variabel orientasi wirausaha (Y) sama dengan 15,020.

b. Koefisien regresi variabel latar belakang etnis $\left(\mathrm{X}_{1}\right)$ sebesar 0,617 , artinya perbedaan latar belakang etnis $\left(\mathrm{X}_{1}\right)$ menentukan orientasi wirausaha $(\mathrm{Y})$.

c. Koefisien regresi variabel kecerdasan adversitas $\left(\mathrm{X}_{2}\right)$ sebesar 0,506, artinya setiap perubahan variabel kecerdasan adversitas $\left(\mathrm{X}_{2}\right)$ akan berpengaruh positif terhadap orientasi wirausaha (Y) sebesar 0,506 dengan asumsi variabel latar belakang etnis $\left(\mathrm{X}_{1}\right)$ dan regulasi diri dalam belajar $\left(\mathrm{X}_{3}\right)$ tidak mengalami perubahan atau konstan. Nilai koefisien regresi positif menunjukkan pengaruh yang searah, artinya jika variabel kecerdasan adversitas $\left(\mathrm{X}_{2}\right)$ naik 1 satuan maka akan berpengaruh pada kenaikan variabel orientasi wirausaha (Y) sebesar 0,506 satuan. Sebaliknya jika variabel kecerdasan adversitas $\left(\mathrm{X}_{2}\right)$ turun 1 satuan maka akan mengakibatkan penurunan variabel orientasi wirausaha (Y) sebesar 0,506 satuan. 
d. Koefisien regresi variabel regulasi diri dalam belajar $\left(\mathrm{X}_{3}\right)$ sebesar 0,387, artinya setiap perubahan variabel regulasi diri dalam belajar $\left(\mathrm{X}_{3}\right)$ akan berpengaruh positif terhadap orientasi wirausaha (Y) sebesar 0,387 dengan asumsi variabel latar belakang etnis $\left(\mathrm{X}_{1}\right)$ dan kecerdasan adversitas $\left(\mathrm{X}_{2}\right)$ tidak mengalami perubahan atau konstan. Nilai koefisien regresi positif menunjukkan pengaruh yang searah, artinya jika variabel regulasi diri dalam belajar $\left(\mathrm{X}_{3}\right)$ naik 1 satuan maka akan berpengaruh pada kenaikan variabel orientasi wirausaha (Y) sebesar 0,387 satuan. Sebaliknya jika variabel regulasi diri dalam belajar $\left(\mathrm{X}_{3}\right)$ turun 1 satuan maka akan mengakibatkan penurunan variabel orientasi wirausaha $(\mathrm{Y})$ sebesar 0,387 satuan.

Hasil analisis regresi linier berganda mengenai pengaruh latar belakang etnis terhadap orientasi wirausaha siswa SMP Negeri 31 Surabaya menunjukkan bahwa latar belakang etnis berpengaruh positif dan signifikan terhadap orientasi wirausaha siswa yang berarti latar belakang etnis dimana seorang siswa berada mempunyai pengaruh besar terhadap orientasi wirausahanya. Nilai positif pada variabel ini menunjukkan bahwa latar belakang etnis memiliki hubungan yang searah dengan orientasi wirausaha siswa yaitu semakin besar pengaruh etnis tertentu pada siswa maka semakin tinggi pula orientasi wirausaha siswa.

Hasil penelitian ini mendukung Kodiran (2004) bahwa latar belakang budaya mempunyai peran dominan dalam pembentukan watak dan kepribadian. Penelitian ini juga melengkapi penelitian Kollman et al. (2007) yang menyatakan bahwa pada awalnya pengusaha dihadapkan dengan berbagai pengaruh dari lingkungannya. Faktor-faktor di lingkungan pengusaha yang dibahas dalam penelitian Kollman et al. (2007) salah satunya adalah budaya, faktor kewirausahaan individu di berbagai negara menjadi mungkin berpengaruh terhadap orientasi wirausaha individu. Berdasar temuan dari penelitian ini maka dapat disimpulkan bahwa latar belakang etnis dimana siswa berada berpengaruh terhadap orientasi wirausahanya. Lingkungan dengan latar belakang etnis tertentu mempengaruhi orientasi wirausaha seseorang.

Berdasarkan hasil analisis regresi linier berganda mengenai pengaruh kecerdasan adversitas terhadap orientasi wirausaha siswa SMP Negeri 31 'Surabaya menunjukkan bahwa kecerdasan adversitas berpengaruh positif dan signifikan terhadap orientasi wirausaha siswa yang berarti semakin tinggi kecerdasan adversitas yang dimiliki seorang siswa maka berpengaruh pada tingginya orientasi wirausaha yang dimiliki. Jika kecerdasan adversitas tinggi maka orientasi wirausahanya juga akan tinggi dengan asumsi variabel bebas lainnya dianggap tetap. Nilai positif pada variabel ini menunjukkan bahwa kecerdasan adversitas memiliki hubungan yang searah dengan orientasi wirausaha siswa yaitu semakin tinggi kecerdasan adversitas siswa maka semakin tinggi pula orientasi wirausaha siswa. Hasil penelitian ini mendukung penelitian yang dilakukan oleh Ullah et al. (2012) yang mendapati sebuah hubungan yang positif antara orientasi wirausaha dan faktor psikologis dan non psikologis.

Menurut Masykur (2007) kecerdasan adversitas merupakan salah satu konsep psikologis yang berintikan tentang kecerdasan dan kemampuan untuk 
menghadapi kesulitan yang menghadang seseorang. Hasil penelitian ini sejalan dengan penelitian yang dilakukan oleh Pratiwi dan Izzati (2013) yang menunjukkan hasil bahwa kecerdasan adversitas memiliki hubungan yang signifikan dengan kemandirian dalam pengambilan keputusan karir dengan arah hubungan yang positif. Penelitian ini juga sependapat dengan penelitian yang dilakukan oleh Oktariningtyas dan Maria (2010) yang menemukan adanya hubungan yang positif dan signifikan antara daya juang dengan motivasi berprestasi. Semakin tinggi daya juang siswa maka akan semakin tinggi juga motivasi berprestasinya dan sebaliknya.

Daya juang adalah istilah lain yang digunakan untuk menyebut kecerdasan adversitas yang dikonsep oleh Stoltz. Kecerdasan adversitas yang dimiliki siswa SMP Negeri 31 Surabaya pada umumnya tinggi. Hal tersebut dapat dilihat dari indikator-indikator kecerdasan adversitas yaitu mengendalikan dan mengelolah peristiwa, mempermasalahkan dirinya, orang lain dan lingkungan, mengakui akibat-akibat kesulitan dan kesediaan untuk bertanggung jawab, jangkauan dampak kesulitan, dan kecepatan dan ketepatan dalam mengatasi masalah yang memiliki nilai rata-rata tinggi. Pada indikator mengendalikan dan mengelolah peristiwa menunjukkan bahwa siswa akan mencari jalan keluar agar permasalahan yang dihadapi segera terselesaikan, siswa merasa yakin dapat mengatasi permasalahan yang sedang dihadapi, siswa menganggap bahwa kesulitan belajar yang dihadapi merupakan masalah yang juga dihadapi oleh teman-teman lainnya, siswa akan berusaha mendapat nilai yang baik pada saat ulangan dengan belajar sungguh-sungguh, dan siswa berusaha menyelesaikan soal-soal ulangan sebaik mungkin agar mendapat nilai yang baik.

Pada indikator mempermasalahkan dirinya, orang lain dan lingkungan menunjukkan bahwa jika siswa mendapat nilai jelek dalam ulangan, maka itu merupakan kesalahannya. Untuk indikator mengakui akibat-akibat kesulitan dan kesediaan untuk bertanggung jawab menunjukkan bahwa jika siswa merusak /menghilangkan barang milik temannya maka ia akan menggantinya, tugas-tugas yang diberikan oleh guru adalah tanggung jawabnya untuk menyelesaikannya, jika dirinya bersalah ia akan mengakuinya dan meminta maaf, dan siswa secara aktif ikut menyelesaikan tugas-tugas kelompok. Pada indikator jangkauan dampak kesulitan menunjukkan bahwa permasalahan yang sedang dihadapinya tidak akan mengganggu kualitas belajarnya, tugastugas yang banyak bukan menjadi beban baginya, siswa akan menyelesaikan masalahnya secepat mungkin, masalah pribadi yang sedang dihadapi tidak akan mempengaruhi prestasi belajarnya dan siswa tidak takut gagal.

Untuk indikator kecepatan dan ketepatan dalam mengatasi masalah menunjukkan bahwa siswa akan menyelesaikan tugas-tugasnya sampai tuntas dan tidak mau setengah-setengah, siswa berusaha menyelesaikan tugastugasnya tepat pada waktunya, siswa akan segera bangkit kembali bila mengalami kegagalan, siswa mengakui kegagalan adalah awal dari kesuksesan dan tidak akan putus asa dalam menghadapi suatu permasalahan. Hasil penelitian menunjukkan bahwa beberapa siswa masih terganggu belajarnya bila sedang menghadapi masalah dan terbebani dengan tugas-tugas yang banyak. Kecerdasan adversitas siswa akan jauh lebih baik jika masalah yang dihadapi siswa tidak akan mengganggu belajarnya dan tugas-tugas yang 
banyak bukan menjadi beban baginya. Hal tersebut sesuai dengan pendapat Stoltz (2007) yang menyatakan bahwa adversity quotient yang rendah pada individu akan membuat kesulitan merembes ke segi-segi lain dari kehidupan seseorang. Kemampuan siswa dalam mengendalikan dan mengelolah peristiwa berkaitan dengan kemandirian siswa, mempermasalahkan dirinya, orang lain dan lingkungan, mengakui akibat-akibat kesulitan dan kesediaan bertanggung jawab berkaitan erat dengan sikap berani mengambil resiko siswa. Sedangkan kecepatan dan ketepatan dalam memecahkan masalah berkaitan erat dengan sikap proaktif dan tanggap terhadap persaingan, sehingga dalam penelitian ini kecerdasan adversitas berpengaruh terhadap orientasi wirausaha siswa.

Berdasarkan hasil analisis regresi linier berganda mengenai pengaruh regulasi diri dalam belajar terhadap orientasi wirausaha siswa SMP Negeri 31 'Surabaya menunjukkan bahwa regulasi diri dalam belajar berpengaruh positif dan signifikan terhadap orientasi wirausaha siswa yang berarti semakin tinggi regulasi diri dalam belajar yang dimiliki seorang siswa maka berpengaruh pada tingginya orientasi wirausaha yang dimiliki. Jika regulasi diri dalam belajar siswa tinggi maka orientasi wirausahanya juga akan tinggi dengan asumsi variabel bebas lainnya dianggap tetap. Nilai positif pada variabel ini menunjukkan bahwa regulasi diri dalam belajar siswa memiliki hubungan yang searah dengan orientasi wirausahanya yaitu semakin tinggi regulasi diri dalam belajar siswa maka semakin tinggi pula orientasi wirausaha siswa. Semakin sering siswa melakukan regulasi diri dalam belajar maka semakin tinggi orientasi wirausahanya. Dalam penelitian yang dilakukan oleh Sungur dan Tekkaya (2006) menunjukkan hasil bahwa regulasi diri dalam belajar memiliki pengaruh yang signifikan terhadap kemandirian. Inayah (2013) dalam penelitiannya menyatakan bahwa terdapat hubungan positif yang signifikan antara regulasi diri dalam belajar dengan motivasi berprestasi pada peserta didik.

Penelitian yang dilakukan Ellianawati dan Wahyuni (2010) menunjukkan bahwa memilih pola belajar sesuai dengan minatnya ternyata berpengaruh pada kenyamanan belajar dan motivasi berkompetisi yang positif sehingga capaian belajarnya lebih baik. Regulasi diri dalam belajar yang dimiliki siswa SMP Negeri 31 Surabaya pada umumnya tinggi. Hal tersebut dapat dilihat dari indikator-indikator kecerdasan adversitas yaitu regulasi diri dalam belajar, konsekuen, kelola lingkungan, orientasi penguasaan dan kemempuan, motivasi intrinsik dan ekstrinsik, relevansi diri, mengatur usaha, waktu dan lingkungan belajar serta mencari bantuan yang memiliki nilai rata-rata tinggi.

Pada indikator regulasi diri dalam belajar menunjukkan bahwa siswa akan mengumpulkan soal-soal ulangan yang terdahulu untuk dipelajari kembali, membaca kembali catatannya walaupun tidak akan ulangan, membuat catatan-catatan ringkas untuk mempermudah belajarnya, ketika membaca buku teks/paket pelajaran menggaris bawahi bagian-bagian yang penting, membaca buku-buku lain selain buku pelajaran untuk menambah wawasan dan mengerjakan soal-soal latihan yang ada dibuku paket pelajaran untuk menguji kemampuannya. Pada indikator konsekuen, kelola lingkungan, orientasi penguasaan dan kemempuan, motivasi intrinsik dan ekstrinsik, serta relevansi diri menunjukkan bahwa siswa menetapkan nilai yang harus dicapai pada setiap mata pelajaran, siswa memastikan bahwa ulangan/tugas/pekerjaannya 
sudah baik dan benar dengan memeriksanya kembali sebelum dikumpulkan, berusaha mendapat nilai ulangan yang terbaik dengan belajar sungguhsungguh, ingin membanggakan orang tua dengan prestasi yang baik, ingin menjadi orang yang berwawasan luas dan akan berusaha menyelesaikan tugastugasnya sebaik mungkin.

Pada indikator mengatur usaha, waktu dan lingkungan belajar serta mencari bantuan menunjukkan bahwa siswa akan bertanya kepada guru, orang tua atau teman jika tidak paham tentang materi pelajaran, berusaha menyelesaikan tugas-tugas tepat waktu, membuat dan mengatur jadwal belajarnya, berusaha menciptakan suasana belajar sesuai dengan kemauannya, berusaha untuk berkonsentrasi pada saat guru menjelaskan materi pelajaran, menyiapkan buku pelajaran dan peralatan sekolah untuk besok pada malam sebelumnya, menata meja belajarnya agar selalu rapi dan mempermudah dalam mencari buku yang saya perlukan, dan ikut bimbingan belajar di luar sekolah untuk meningkatkan prestasi belajarnya. Berdasarkan temuan yang dikemukakan diatas maka dapat disimpulkan bahwa regulasi diri dalam belajar siswa akan jauh lebih baik jika siswa membaca kembali catatannya walaupun tidak akan ulangan, membuat catatan-catatan ringkas untuk mempermudah belajarnya, dan ikut bimbingan belajar di luar sekolah untuk meningkatkan prestasi belajarnya.

Kebiasaan meregulasi diri dalam belajar membawa pengaruh terhadap kemandirian, motivasi berprestasi, motivasi berkompetisi dan proaktif seorang siswa karena siswa yang mempunyai kebiasaan meregulasi diri dalam belajarnya akan berusaha untuk mencapai tujuan-tujuan dalam belajarnya ( Zimmerman, 2004). Kemandirian, motivasi berprestasi, motivasi berkompetisi dan proaktif merupakan bagian dari indikator-indikator orientasi wirausaha. Kemampuan siswa dalam regulasi diri dalam belajar berkaitan dengan kemandirian siswa dan sikap proaktif, konsekuen, kelola lingkungan, orientasi penguasaan dan kemampuan, motivasi intrinsik dan ekstrinsik serta relevansi diri berkaitan erat dengan kemandirian siswa dan sikap berani mengambil resiko siswa. Sedangkan kemampuan dalam mengatur usaha, waktu dan lingkunagan belajar serta mencari bantuan berkaitan erat dengan sikap proaktif siswa, sehingga dalam penelitian ini regulasi diri dalam belajar siswa berpengaruh terhadap orientasi wirausaha siswa.

Berdasarkan hasil analisis data yang dilakukan menunjukkan bahwa latar belakang etnis, kecerdasan adversitas dan regulasi diri dalam belajar siswa secara simultan berpengaruh positif dan signifikan terhadap orientasi wirausaha siswa SMP Negeri 31 Surabaya. Hal ini berarti semakin lama siswa berada pada lingkungan etnis tertentu, semakin tinggi kecerdasan adversitas siswa dan semakin tinggi kemampuan regulasi diri siswa dalam belajar maka semakin tinggi juga orientasi wirausahanya. Sebaliknya, semakin singkat waktu seorang siswa berada di lingkungan latar belakang etnis tertentu, semakin rendah kecerdasan adversitasnya dan semakin jarang melakukan regulasi diri dalam belajarnya maka semakin rendah orientasi wirausahanya. Secara parsial ketiganya memiliki pengaruh yang hampir sama dengan nilai yang tidak jauh berbeda. Latar belakang etnis secara simultan mempunyai pengaruh yang lebih tinggi terhadap orientasi wirausaha siswa dibandingkan dengan dua variabel bebas lainnya yaitu kecerdasan adversitas dan regulasi diri dalam belajar. Hal 
ini karena siswa dengan berlatar belakang etnis tertentu akan dipengaruhi oleh budaya yang ada disekitarnya.

Lingkungan dengan latar belakang etnis Jawa dan Madura memiliki budaya-budaya tertentu dalam menumbuhkan orientasi wirausaha. Hal ini dibuktikan dengan dimilikinya orientasi wirausaha yang tinggi dalam diri siswa. Kecerdasan adversitas mempunyai pengaruh terhadap orientasi wirausaha siswa yang lebih rendah dari pengaruh latar belakang etnis dan lebih tinggi dari pengaruh regulasi diri dalam belajar siswa.

Pada penelitian ini menunjukkan bahwa sebagian besar siswa memiliki kecerdasan adversitas yang tinggi, hal ini ditunjukkan dengan kemampuan siswa dalam mengendalikan masalah yang dihadapi, mengetahui dari mana masalah itu ada, mengakui akibat-akibat kesulitan, kesediaan untuk betanggung jawab, menghindari agar masalah yang dihadapi tidak mempengaruhi hal yang lainnya serta cepat dan tepat dalam memecahkan masalah. Regulasi diri dalam belajar mempunyai pengaruh yang paling rendah jika dibandingkan dengan pengaruh latar belakang etnis dan pengaruh kecerdasan adversitas siswa terhadap orientasi wirausaha siswa. Pada penelitian ini menunjukkan bahwa sebagian besar siswa memiliki regulasi diri dalam belajar yang tinggi, hal ini ditunjukkan dengan kemampuan siswa dalam strategi regulasi kognitif, strategi regulasi motivasional dan strategi behavioral akademik.

Dari hasil penelitian yang diuraikan diatas menunjukkan bahwa latar belakang etnis, kecerdasan adversitas dan regulasi diri dalam belajar memberikan pengaruh positif dan signifikan terhadap orientasi wirausaha siswa. Hasil penelitian ini mendukung penelitian yang dilakukan oleh Ullah dkk (2012), dalam penelitiannya orientasi wirausaha seseorang dipengaruhi oleh faktor psikologis dan faktor non psikologis. Faktor psikologis yang mempengaruhi yaitu motivasi berprestasi, keyakinan bahwa dirinya adalah penentu nasib mereka sendiri, toleransi terhadap ambiguitas dan peran intuisi sedangkan untuk faktor non psikologis yang mempengaruhi yaitu peran pendidikan, peran beberapa ketrampilan/keragaman ketrampilan, peran hubungan formal/sosial, dan peran hubungan informal/pribadi.

\section{SIMPULAN}

Ada perbedaan signifikan latar belakang etnis terhadap orientasi wirausaha. Artinya semakin lama seorang siswa berada di lingkungan berlatar belakang etnis Madura maka semakin tinggi orientasi wirausahanya. Sebaliknya, semakin singkat waktu seorang siswa berada di lingkungan berlatar belakang etnis Madura maka semakin rendah orientasi wirausahanya. Ada pengaruh positif dan signifikan kecerdasan adversitas terhadap orientasi wirausaha. Artinya semakin tinggi kecerdasan adversitas yang dimiliki seorang siswa maka semakin tinggi orientasi wirausahanya. Sebaliknya semakin rendah kecerdasan adversitas seorang siswa maka semakin rendah juga orientasi wirausahanya. Ada pengaruh positif dan signifikan regulasi diri dalam belajar terhadap orientasi wirausaha. Artinya semakin sering siswa melakukan regulasi diri dalam belajarnya maka semakin tinggi orientasi wirausahanya. Sebaliknya, semakin jarang seorang siswa melakukan regulasi diri dalam belajarnya maka semakin rendah orientasi wirausahanya. Ada pengaruh positif dan 
signifikan latar belakang etnis, kecerdasan adversitas dan regulasi diri dalam belajar terhadap orientasi wirausaha. Artinya semakin lama seorang siswa berada di lingkungan latar belakang etnis Madura, semakin tinggi kecerdasan adversitasnya dan semakin sering melakukan regulasi diri dalam belajarnya maka semakin tinggi orientasi wirausahanaya. Sebaliknya, semakin singkat waktu seorang siswa berada di lingkungan latar belakang etnis Madura, semakin rendah kecerdasan adversitasnya dan semakin jarang melakukan regulasi diri dalam belajarnya maka semakin rendah orientasi wirausahanya.

\section{DAFTAR RUJUKAN}

Cobb, R.J. (2003). The Relationship between Self-Regulated Learning Behaviors and Academic Performence in Web-based Courses. Desertation. Blacksburg Virgiania.

Ellianawati dan Wahyuni, S. (2010). “ Pemanfaatan model self-regulated learning sebagi upaya peningkatan kemampuan belajar mandiri pada mata kuliah optik". Jurnal pendidikan fisika Indonesia 6, pp. 35-39.

Filho, M.K.C. (2004). "A review on theories of self-regulated learning". Bull.Grad.Shool Educ. Hiroshima Univ, Part III, 50, pp. 437-445.

Frese, M. Brantjes, A. \& Hoorn, R. (2002). "Psychological Success Factors of Small Scale Businesses in Namibia: The Roles of Strategy Process, Entrepreneurial Orientation and the Environment". Journal of Developmental Entrepreneurship. 7: 259-282.

Kodiran. (2004). "Pewarisan budaya dan kepribadian”. Humaniora. Vol 16 No. 1, pp.10-16.

Lumpkin, G.T., dan Dess, G.G. (1996). "Clarifying the entrepreneurial orientation construct and linking it to performance". The academy of management review, Vol.21 No. 1, pp. 135-172.

Masykur, A.M. (2007). "Kewirausahaan pada mahasiswa ditinjau dari adversity quotient". Jurnal psikologi proyeksi. Vol. 2 No.2.

Oktariningtyas. dan Maria, A. (2010). "Hubungan antara daya juang dengan motivasi berprestasi pada siswa kelas 7 SMP Strada Bhakti Utama Jakarta Selatan”. Tesis. (tidak diterbitkan). Jakarta: Fakultas Keguruan Ilmu Pendidikan Unika Atma Jaya. http://lib.atmajaya.ac.id/default.aspx?tabID $=61 \&$ src $=$ k\&id=163859

Pratiwi, I. dan Izzati, U.A. (2013). “ Hubungan antara adversity quotient dengan kemandirian dalam pengambilan keputusan karir pada siswa kelas XI SMK Negeri 2 Surabaya”. Jurnal penelitian psikologi. Vol. 1 No. 2.

Stoltz, P.G. (2007). Adversity quotient, mengubah hambatan menjadi peluang. Jakarta: PT Gramedia Widiasarana Indonesia.

Sungur, Semra and Tekkaya, C. (2006). " Effects of problem-based learning and traditional instruction on self-regulated learning".The journal of educational research. Vol. 99 No. 5, pp.307-317. 
Susanti, N. (2013)." Hubungan antara dukungan sosial dan daya juang dengan orientasi wirausaha pada mahasiswa program profesi apoteker Universitas Ahmad Dahlan Yogyakarta. www. jogjapress.com, 20 Maret 2015.

Sutomo, D. (2007). Menjadi entrepreneur jempolan. Jakarta: Republika.

Ullah, H., Farooq, M.A., and Ahmad, Z.M. (2012). "A study of psychological and non psychological factors of owner influencing entrepreneural orientation : Evidence from Khyber Pakhtunkhwa-Pakistan". Management science and engineering. Vol. 6 No.1, pp. 44-55.

Vinig, T.G., and Dorresteiin, W. (2007). "Determinants of entrepreneural orientation among students - A comparative study of Dutch, Norwegian and Israeli Students". http://papers.ssrn.com/sol3/papers.cfm?abstract_id=1020576

Wolters, C.A., Pintrich, P.R., and Karabenick, S.A. (2003). "Assesing Academic Self-regulated Learning. Prepared for the Conference on Indicators of Positive Development: Child Trends. Diunduh dari : http://www.childtrends.org/Files/Child_Trends2003_03_12_PD_PDConf WPK.pd.

Zimmerman B.J. (2004). "A social cognitive view of self-regulated academic larning". Journal of educational psychology. Vol. 4 No. 2, pp. 22-63. 